WellBeing International

WBI Studies Repository

$10-2013$

\title{
General Principles for the Welfare of Animals in Production Systems: The Underlying Science and Its Application
}

\author{
David Fraser \\ University of British Columbia \\ Ian J.H. Duncan \\ University of Guelph \\ Sandra A. Edwards \\ Newcastle University \\ Temple Grandin \\ Colorado State University \\ Neville G. Gregory \\ Royal Veterinary College
}

See next page for additional authors

Follow this and additional works at: https://www.wellbeingintlstudiesrepository.org/farawel

Part of the Agribusiness Commons, Animal Studies Commons, and the Business Law, Public Responsibility, and Ethics Commons

\section{Recommended Citation}

Fraser, D., Duncan, I. J., Edwards, S. A., Grandin, T., Gregory, N. G., Guyonnet, V., ... \& Mench, J. A. (2013). General principles for the welfare of animals in production systems: the underlying science and its application. The Veterinary Journal, 198(1), 19-27.

This material is brought to you for free and open access by WellBeing International. It has been accepted for inclusion by an authorized administrator of the WBI Studies Repository. For more information, please contact wbisr-info@wellbeingintl.org.

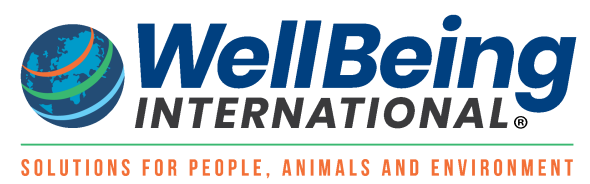




\section{Authors}

David Fraser, Ian J.H. Duncan, Sandra A. Edwards, Temple Grandin, Neville G. Gregory, Vincent Guyonnet, Paul H. Hemsworth, Stella M. Huertas, Juliana M. Huzzey, David J. Mellor, Joy A. Mench, Marek Špinka, and $\mathrm{H}$. Rebecca Whay 


\section{General Principles for the Welfare of Animals in Production Systems: The Underlying Science and Its Application}

David Fraser ${ }^{1}$, Ian J.H. Duncan ${ }^{2}$, Sandra A. Edwards ${ }^{3}$, Temple Grandin ${ }^{4}$, Neville G. Gregory ${ }^{5}$, Vincent Guyonnet $^{6}$, Paul H. Hemsworth ${ }^{7}$, Stella M. Huertas ${ }^{8}$, Juliana M. Huzzey ${ }^{1}$, David J. Mellor ${ }^{9}$, Joy A. Mench $^{10}$, Marek Špinka ${ }^{11}, \mathrm{H}$. Rebecca Whay ${ }^{12}$

${ }^{1}$ University of British Columbia

2 University of Guelph

${ }^{3}$ Newcastle University

${ }^{4}$ Colorado State University

${ }^{5}$ Royal Veterinary College

${ }^{6}$ The International Egg Commission
${ }^{7}$ University of Melbourne

${ }^{8}$ Universidad de la República

${ }^{9}$ Massey University

${ }^{10}$ University of California - Davis

${ }^{11}$ Institute of Animal Science

12 University of Bristol

\section{KEYWORDS}

animal welfare, animal health, animal husbandry, animal production

\section{ABSTRACT}

In 2012, the World Organisation for Animal Health adopted 10 'General Principles for the Welfare of Animals in Livestock Production Systems' to guide the development of animal welfare standards. The General Principles draw on half a century of scientific research relevant to animal welfare: (1) how genetic selection affects animal health, behaviour and temperament; (2) how the environment influences injuries and the transmission of diseases and parasites; (3) how the environment affects resting, movement and the performance of natural behaviour; (4) the management of groups to minimize conflict and allow positive social contact; (5) the effects of air quality, temperature and humidity on animal health and comfort; (6) ensuring access to feed and water suited to the animals' needs and adaptations; (7) prevention and control of diseases and parasites, with humane euthanasia if treatment is not feasible or recovery is unlikely; (8) prevention and management of pain; (9) creation of positive human-animal relationships; and (10) ensuring adequate skill and knowledge among animal handlers. Research directed at animal welfare, drawing on animal behaviour, stress physiology, veterinary epidemiology and other fields, complements more established fields of animal and veterinary science and helps to create a more comprehensive scientific basis for animal care and management.

\section{Introduction}

In 2012, the 178 member nations of the World Organisation for Animal Health (also known by its French acronym Office International des Epizooties, OIE) ${ }^{1}$ adopted 10 'General Principles for the Welfare of Animals in Livestock Production Systems' to guide the development of specific standards for various 
animal species (OIE, 2012). Although stated in simple terms, the General Principles draw on half a century of rapidly increasing scientific research relevant to animal welfare.

Animal welfare science emerged as an interdisciplinary field of research in the 1970s (Duncan, 1970; Wood-Gush et al., 1975; Dawkins, 1977). The initial stimulus for this work came from public concern over the welfare of animals kept in the then-new confinement production systems. Early research that explicitly addressed animal welfare was largely based on the fields of animal behaviour (Broom and Fraser, 2007) and stress physiology (Broom and Johnson, 1993), but the relevance of many other fields was quickly recognized. These include veterinary epidemiology, environmental physiology, environmental design, comparative psychology and studies of the behaviour of animal handlers, along with conventional fields such as nutrition and microbiology (Fraser, 2008; Mellor et al., 2009; Appleby et al., 2011).

Although the research was originally intended to resolve problems in confinement production systems, many of the scientific methods and findings have proven applicable to animals in a wider range of circumstances. The General Principles were designed to capture and summarize the key insights arising from this research. This article uses the General Principles as a framework to illustrate the broad range of science relevant to animal welfare and its application to animal welfare standards and practices.

\section{Genetic selection should always take into account the health and welfare of animals}

Genetic selection has been used for millennia to improve the production traits of agricultural animals. Research on animal welfare complements this work by identifying and mitigating often-unintended health and other consequences of genetic change, and by identifying ways that selection can improve animal welfare.

Despite the gains in animal productivity that have been made, genetic selection for extreme production or physical traits can result in abnormalities that impair normal biological functioning. For example, genetic selection for 'double-muscling' in beef cattle breeds such as the Belgian Blue has led to greater risk of dystocia because fetal size is too large for the pelvis of the cow (Murray et al., 2002). Among dairy cattle that have been highly bred for milk yield, high milk production is associated with an increased incidence of fertility problems and metabolic disorders, such as ketosis (Erb et al., 1985).

Osteoporosis is widespread in commercial laying hens because genetic selection for high rates of egg laying have led to excessive loss of bone calcium that is repartitioned to egg shells (Whitehead, 2004; Webster, 2004). Osteoporosis increases the risk of fractured bones in caged birds when they are handled and in non-cage systems when hens fall or sustain injuries during flight (Lay et al., 2011).

The breeding of pigs for rapid growth and carcass leanness has led to increased osteochondrosis and leg weakness, and to changes in muscle composition that can impair the ability to withstand environmental stresses (Rauw et al., 1998). Piglet viability is also affected through reduced physiological maturity at birth, and concurrent selection for prolificacy has resulted in greater numbers of litter-mates competing for teats (Edwards, 2002). Selection of pigs for rapid muscle deposition has also been linked to 'tail-biting', whereby pigs chew or bite the tails of others in the group to the point of causing injury (Breuer et al., 2005).

Intense genetic selection can also contribute to abnormal behaviour in birds. Selection of broiler chickens for fast growth has resulted in increased appetite (Siegel and Wisman, 1966), such that birds kept for breeding need to be feed-restricted to prevent obesity and reproductive failure (Mench, 2002; de Jong and Guémené, 2011). Birds on such limited diets show signs of chronic hunger, including pacing, stereotyped pecking, and excessive water intake (Savory and Maros, 1993). 
Despite such challenges, there are positive examples of genetic section being used to promote animal welfare. In pigs, active selection against the 'halothane gene' has reduced stress-susceptibility and malignant hyperthermia (Wendt et al., 2000). Breeding dairy cattle for disease resistance, ease of calving and fertility can improve animal welfare, while arguably giving better economic returns than breeding for high milk production alone (Lawrence et al., 2004). Techniques such as quantitative trait locus mapping provide new opportunities to select against problematic behaviour, such as feather-pecking in chickens (Jensen et al., 2008). The application of group selection to reduce social behaviour problems in laying hens has resulted in strains that can be kept in cages with minimal pecking damage (Muir and Craig, 1998). These same methods can reduce aggression and competition for feed (Bell et al., 2004; Thogerson et al., 2009). Genetic selection can also help to eliminate the need for painful procedures. For example, selective breeding of cattle for the 'polled' (hornless) allele avoids the need for surgical dehorning (Stookey and Goonewardene, 1996).

Good animal welfare also requires a satisfactory match between genetics and the environment. In tropical and sub-tropical environments in Asia and Africa, indigenous breeds of chicken perform better than commercial lines because of their greater tolerance for high temperatures and tropical diseases (Dana et al., 2010; Dessie et al., 2011). Similarly, cattle indigenous to the tropics (Bos indicus) are well adapted to hot, humid environments and exhibit resistance to tropical diseases, including trypanosomiasis (Mirkena et al., 2010). In contrast, European breeds (Bos taurus), when introduced to the tropics because of their high milk yield potential, tend to have higher mortality rates and poorer reproductive performance than indigenous breeds because of their more limited ability to adapt to tropical climates, feeds and diseases (Pearson de Vaccaro, 1990; Huertas et al., 2009). Breeding programmes have sometimes been used to improve the environmental fit of animals to such climates. For example, the Charbray and Santa Gertrudis breeds of beef cattle (crosses of $B$. indicus with Europe-sourced breeds) have been bred to suit hot environments (Porter, 2002).

2. The physical environment, including the substrate (walking surface, resting surface etc.), should be suited to the species and breed so as to minimise risk of injury and transmission of diseases or parasites to animals

Some of the earliest welfare concerns regarding production animals arose from an apparent mismatch between the animals' adaptations and the environments in which they were kept. Various research methods, including veterinary epidemiology (Ekesbo, 1966), have been used to explore how an animal's environment influences its health.

Some environments contribute directly to injuries. Pigs in many confinement systems are kept on concrete floors which can cause pressure injuries, especially over bony protuberances such as the shoulders (Herskin et al., 2011). Leg injuries in suckling piglets appear to be caused by both abrasion and build-up of frictional heat when piglets scramble for access to the sow's udder on floors that do not provide sufficient traction (Phillips et al., 1992). 'Slatted' floors (with openings to allow feces to fall below) can cause hoof lesions, especially if slat dimensions and quality are inappropriate for the size of the animal (Kilbride et al., 2009).

Hoof disorders of dairy cattle in confinement systems are more likely on concrete (slatted or solid) floors than rubber floors (Fjeldaas et al., 2011). In pasture-based systems cows often traverse long distances (2-10 km per day) to reach the milking parlour; such travel can increase the risk of foot injuries and lameness, particularly when the terrain is rough and uneven (Martino et al., 2011).

Laying hens can develop several kinds of foot injuries related to the surfaces on which they stand and walk (Lay et al., 2011). Ulcerative pododermatitis is seen most often in hens housed in litter-based 
systems because of the presence of wet litter and feces. Hyperkeratosis is more common in birds held in cages; contributory factors include poor galvanizing of the cage floor and steep floor slope (Tauson, 1998; Weitzenbürger et al., 2006).

Environments can further compromise animal welfare if they promote the multiplication and spread of pathogens and parasites. Pathogens in soil, bedding and feed are important in the occurrence of listeriosis (Listeria spp.) and coxiellosis ('Q Fever', Coxiella burnetii) in sheep (Mearns, 2007; Scott, 2007). On dairy cattle farms, contamination with bacteria that cause mastitis tends to be more severe in bedding consisting of digested fecal solids, intermediate on recycled sand and shavings, and lowest on clean sand (Godden et al., 2008). The spread of digital dermatitis in dairy cattle is facilitated by wet walking surfaces covered with feces (Evans et al., 2012). The spread of virulent footrot (Dichelobacter nodosus) in sheep and goats is facilitated by wet conditions under foot (Iqbal et al., 2011). Red mite (Dermanyssus gallinae), a nest-dwelling parasite of chickens that can cause anaemia and deaths, resides in cracks and crevices in the bird's environment and is especially common in non-cage systems (Chauve, 1998; Lay et al., 2011).

3. The physical environment should allow comfortable resting, safe and comfortable movement, including normal postural changes, and the opportunity to perform types of natural behaviour that animals are motivated to perform

Certain types of environments can lead to welfare problems by unduly constraining the basic movements and behaviour of animals. Relevant research includes studies of abnormal behaviour and stress physiology in different environments, studies of the environmental preferences of animals and studies that quantify an animal's motivation to carry out given types of natural behaviour, for example by measuring how much work an animal will perform in order to do so (Dawkins, 2004, 2008; Fraser and Nicol, 2011).

Inadequate space is a common problem, especially if animals are crowded to the point that feeding, resting and other basic types of behaviour are affected. In dairy production, overcrowding has been associated with cattle spending less time feeding and lying, and with increased aggression; these changes may help to explain increased stress responses, particularly among individuals of low social rank in the herd (Huzzey et al., 2006, 2012; Fregonesi et al., 2007a). Overcrowding increases aggression, injuries and stress responses in pregnant pigs (Barnett et al., 1992; Salak-Johnson et al., 2007). Overcrowding of caged hens can lead to a reduction in survival and productivity (Adams and Craig, 1985; Bell et al., 2004).

Behaviour is affected by the quality as well as the quantity of the space. Sows slip less when changing posture on rubber mats compared to metal slatted floors (Boyle et al., 2000). Growing pigs are able to move from standing to lying more quickly, and with less injury, on floors that provide better cushioning and grip (Scott et al., 2009). Rubber flooring (compared to hard concrete) improves the gait of dairy cattle, promoting longer strides and better joint flexion, particularly for lame animals (Flower et al., 2007). The quality of the bedding is a key factor for comfortable resting; for example, cattle prefer to lie on dry rather than wet bedding and they rest for a shorter time if only wet bedding is available (Fregonesi et al., 2007b).

Animal welfare concerns arise if very small or barren enclosures cause frustration in animals (defined as an aversive state arising when animals are prevented from performing behaviour that they are strongly motivated to perform; Fraser, 2008). In domestic fowl, a strong motivation to perform 'nest-building' behaviour is triggered by hormonal events at ovulation, $24 \mathrm{~h}$ earlier (Wood-Gush and Gilbert, 1973). Under natural conditions, the hen separates from the flock 60-90 min before an egg is laid, seeks and enters a nesting site, and then performs nest-building activity (Duncan and Kite, 1989). Studies using measures of motivation strength, such as pushing against a weighted door, show that pre-laying hens are 
highly motivated to find a nesting site; hence, an inability to nest is likely to cause significant frustration (Duncan and Kite, 1987; Follensbee et al., 1992). In cages where nesting is impossible, many hens develop stereotyped back-and-forward pacing, a behaviour characteristic of frustration in this species (Duncan, 1970).

Pregnant sows also show pronounced nest-building activity before parturition (Jensen, 1986). If space is too limited for the behaviour to occur, the animals often show behavioural and physiological signs of stress, and have a greater tendency to attack their piglets (Jarvis et al., 2004).

Domestic fowl kept in non-cage systems prefer to roost on high perches at night if these are provided (Blokhuis, 1983, 1984), but standard cages prevent this behaviour. Hens show strong motivation (e.g., by pushing a weighted door) to gain access to perches for roosting, and hens accustomed to roosting show signs of frustration when they are denied access to perches (Olsson and Keeling, 2002). Hence, prevention of roosting is likely to be another cause of frustration. On the basis of such research, there is a growing trend for animal welfare standards to require that hens be allowed to perch and nest.

\section{Social grouping of animals should be managed to allow positive social behaviour and minimise injury, distress and chronic fear}

Production animals are often kept in artificial groups that can either foster positive social behaviour or lead to aggression, injury and chronic fear. Pigs in the wild live in family groups of mixed gender, with males leaving the group when they reach sexual maturity. However, in normal farming practice, males are typically kept in groups of the same age, often with females. If the males are sexually intact, this can result in aggression and sexual 'riding' as the animals reach puberty, causing behavioral disruption, lameness and other injuries (Rydhmer et al., 2006).

Re-grouping of animals can disrupt established social relations. In dairy cattle, competitive displacements at feeding increased two-fold on the day when unfamiliar cattle were mixed together, while social grooming decreased sharply (von Keyserlingk et al., 2008). Mixing young and old animals also can have undesired consequences. When first-lactation and older cows were grouped together on pasture, they spent less time eating, more time in competitive interactions, and produced less milk than similar cattle kept in groups of uniform age (Phillips and Rind, 2001). Introduction of unfamiliar pigs into a group disrupts the social order and leads to fighting that can cause injuries and sometimes death (Turner et al., 2010). Plasma cortisol concentrations are increased for several days in pigs after social disruption (Barnett et al., 1996).

In contrast, allowing animals to form and maintain stable associations can create a positive social environment and improve their ability to cope with new stressors. Calves raised in groups form social bonds (Duve and Jensen, 2011) and cows that have been living together during pregnancy mutually synchronize their behaviour once milk production begins (Gygax et al., 2010). Sows recognize and respond peacefully to familiar pigs, even after several weeks of separation (Arey, 1999). The presence of familiar individuals can reduce the stress response to challenging situations, such as mixing with unfamiliar animals (Rault, 2012). For example, the presence of a familiar pig reduces the physiological stress response to social defeat (Ruis et al., 2001). Heifers introduced into groups of older cows received half of the aggression and showed less disruption of resting if they were accompanied by one familiar individual rather than being moved alone (Gygax et al., 2009; Neisen et al., 2009).

Adequate space and social company can also stimulate play activities that have various benefits. In suckling piglets, play is increased in environments with ample space and enrichment, and which allow free interactions with the dam or piglets from other litters (Chaloupková et al., 2007; Oostindjer et al., 
2011). Play behaviour appears to be rewarding for piglets, since piglets exhibit anticipation behaviour if the opportunity to play is signaled before-hand (Dudink et al., 2006). High levels of pre-weaning play also promote play later in life and decrease later aggression and injuries (Donaldson et al., 2002; Dudink et al., 2006).

5. Air quality, temperature and humidity in confined spaces should support good animal health and not be aversive to animals. Where extreme conditions occur, animals should not be prevented from using their natural methods of thermoregulation

Air quality is important for the welfare of confined animals. Indoor poultry units often have high levels of ammonia and dust. High levels of atmospheric ammonia can cause keratoconjunctivitis in poultry (Quarles and Kling, 1974), as well as damage to the lungs and trachea (Al-Mashhadani and Beck, 1985). Production efficiency is often compromised when air quality is poor; for example, feed efficiency of chickens decreases at ammonia levels of 25-60 parts per million (ppm) (Quarles and Kling, 1974; Beker et al., 2004). In buildings housing pigs, ammonia and other gases released from feces stored under slatted floors can irritate the respiratory tract, and sudden releases of hydrogen sulphide, especially when manure is agitated for pumping out, can prove fatal (Donham et al., 1988).

Even at levels that do not cause detectable pathology, poor quality air can be aversive to animals. When given the choice, young pigs spend more time in clean air than in air containing ammonia, even at relatively low concentrations (10-20 ppm) (Jones et al., 1996). Broiler chickens have been shown to avoid ammonia at $20 \mathrm{ppm}$ and higher, even if they have been exposed to such concentrations for most of their lives (Jones et al., 2005).

Poor air quality can also affect animal welfare by increasing the risk of infectious disease. For example, the risk of bovine respiratory disease is influenced by airborne dust particles, humidity and poor ventilation (van der Fels-Klerx et al., 2000; Snowder et al., 2006).

Protection from extreme weather by access to shelter or shade is also important for animal welfare. In hot weather, the body temperature of cattle can be lowered and their feed intake increased by shade, fans, sprinklers and building designs that enhance passive ventilation (West, 2003; Tucker et al., 2008). Pigs, which lack sweat glands, are very susceptible to heat stress. In hot weather, they can lose significant heat by evaporative cooling if allowed to express their natural wallowing behaviour (Bracke and Spoolder, 2011); showers can assist cooling if wallowing cannot be accommodated (Huynh et al., 2006).

6. Animals should have access to sufficient feed and water, suited to the animals' age and needs, to maintain normal health and productivity and to prevent prolonged hunger, thirst, malnutrition or dehydration

Many decades of nutritional research have led to major improvements in the composition of diets; research on animal welfare complements this work by focusing on how animals gain adequate access to feed and water, and how diets and feeding systems influence the health and behaviour of animals.

Cattle in semi-arid rangeland environments may fail to eat and drink if the available water is unpalatable, as may occur if evaporation leads to a high concentration of magnesium sulphate (Grout et al., 2006). Feed contaminants, such as mycotoxins, can also lead to animals refusing to eat (D'Mello et al., 1999).

The social and physical environment can have major effects on feed and water intake. Inadequate space at the feed trough can create competition that limits feed intake in hens (Bell et al., 2004) and cattle (Proudfoot et al., 2009). The social and physical environment can also interact. Pigs in a group have 
relatively similar feed intake if there is ample access to feeders, but the lowest ranking pigs eat less than the socially dominant animals when feeder space is limited (Hansen et al., 1982).

When pregnant sows are fed concentrated commercial diets, their intake is generally restricted in order to prevent obesity. Such animals are in a chronic state of hunger, which appears to promote bar-biting and other stereotyped behaviour (Appleby and Lawrence, 1987; Lawrence and Terlouw, 1993). The inclusion of dietary fibre helps to reduce such behaviour, presumably by increasing a sense of post-prandial satiety, especially if highly fermentable fibre is used (Meunier-Salaun et al., 2001; de Leeuw et al., 2008).

\section{Diseases and parasites should be prevented and controlled as much as possible through good management practices. Animals with serious health problems should be isolated and treated promptly or killed humanely if treatment is not feasible or recovery is unlikely}

In view of the recognized connection between animal welfare and animal health (OIE, 2012), prevention and control of diseases and parasites are widely regarded as fundamental to animal welfare. Standards and practices can contribute to animal welfare by preventing and controlling diseases and parasites at four levels.

Firstly, protection for individual animals can be provided by a combination of hygiene, vaccination and anti-parasite treatments. For example, comprehensive vaccination programmes protect laying hens from many diseases (Cutler, 2002), especially if biosecurity, quarantine and other measures are also used (Swayne, 2006).

Secondly, the spread of disease within a farm can often be limited by management routines such as 'all-in all-out' systems for pigs, which involve cleaning and disinfection of accommodation between agesegregated batches. This reduces the environmental concentration of micro-organisms and prevents vertical transmission of diseases, such as porcine circovirus-associated disease (Madec et al., 2008) and respiratory disease (Stärk, 2000).

Thirdly, biosecurity barriers can prevent the entry of specific diseases into individual farms. Isolation of poultry from wild birds or rodents greatly reduces the risk of avian influenza and infection with Salmonella spp. (Martin, 2011). Trichinosis (Trichinella spiralis) in pigs is now rare in some countries, at least partly because modern facilities help to isolate pigs from rodent vectors (Gamble and Bush, 1999). Swine dysentery (Brachyspira hyodysenteriae) in the USA is also thought to have declined greatly, partly because of the shift toward larger, indoor housing units that have limited the spread of the disease from farm to farm (Hampson et al., 2006).

Fourthly, well-managed regional programmes can eliminate certain diseases over large areas. For example, concerted regional or national programmes, combined with strict biosecurity and the regular testing and elimination of positive flocks, have essentially eradicated poultry diseases such as fowl typhoid (Salmonella enterica serovar Gallinarum) and pullorum (Salmonella enterica serovar Pullorum) in many countries (Shivaprasad and Barrow, 2008).

Isolating sick individuals may be important to prevent the spread of contagious diseases (Fox and Gay, 1993; Houe, 1995). However, social isolation is a cause of stress in many animals (Minton et al., 1992; Boissy and Le Neindre, 1997). Hence, communal 'hospital pens' are often used to facilitate the treatment of sick animals while separating them from healthy animals.

Euthanasia is important to prevent excessive suffering where treatment is unlikely to resolve a disease. Guidelines for euthanasia (AVMA, 2013) have been developed on the basis of research into humane slaughter (Gregory, 1998; Grandin, 2010) and euthanasia (Woods et al., 2010). The guidelines provide 
criteria for when euthanasia should be conducted (Woods et al., 2010) and research-based advice on pre-euthanasia handling, available methods of euthanasia, their efficacy and safety, and their implications for both animal welfare and the disposal or use of carcasses (FAWC, 2003; Shimshony and Chaudry, 2005).

\section{Where painful procedures cannot be avoided, the resulting pain should be managed to the extent that available methods allow}

Painful procedures, such as castration and dehorning, are often used for animal management purposes or to prevent future injuries. Research using behavioural and physiological indicators of pain, including vocalization, physical reactions and hormonal stress responses, has identified practical approaches for pain management for some such procedures (Weary et al., 2006).

The level of pain caused by procedures such as branding and castration depends on the specific methods used. In cattle, freeze branding appears to cause less pain than hot-iron branding (Lay et al., 1992; Schwartzkopf-Genswein et al., 1998) and cautery disbudding appears to cause less pain than amputation dehorning (Stafford and Mellor, 2005). Behavioural and physiological evidence indicates that pain can be mitigated or eliminated by the combined use of local anaesthesia and a non-steroidal antiinflammatory drug in the case of amputation dehorning of calves (Stafford and Mellor, 2005, 2011; Stewart et al., 2009) and by local anaesthesia for rubber-ring castration of lambs (Mellor and Stafford, 2000).

Many poultry are beak-trimmed or bill-trimmed to prevent injury and death due to feather pecking, aggression and cannibalism (Hester and Shea-Moore, 2003). Methods for beak-trimming include cutting and cauterizing the beak, or applying infrared energy to the area of the beak to be removed. Both methods appear to cause similar short-term pain (Marchant-Forde et al., 2008; McKeegan and Philbey, 2012), but the infrared technique does not produce an open wound and also reduces the risk of chronic pain or other adverse consequences associated with hot-blade trimming (Hester and Shea-Moore, 2003; Gentle, 2011). Genetic selection shows promise of reducing or eliminating the harmful behaviours of birds that are currently mitigated by beak-trimming (Hester and Shea-Moore, 2003; Glatz, 2005).

The sharp teeth of newborn piglets are sometimes clipped or ground to reduce damage to the sow and litter-mates during competition for teats (Fraser, 1975). The extent of pain involved is uncertain, although the resulting tissue damage may cause later pain (Prunier et al., 2005). There are advantages to selective clipping, either by clipping only litters where teat competition is significant, or by leaving smaller piglets with intact teeth to improve their competitiveness and survival (Fraser and Thompson, 1991; Robert et al., 1995).

In some countries, young pigs are routinely castrated to prevent the risk of unpleasant male odours in the meat. This process causes severe acute pain (Taylor and Weary, 2000) and may cause longer-term pain from post-surgical inflammation. General or local anaesthesia reduces the level of surgical pain (White et al., 1995), but presents other challenges, including the stress of additional handling, plus uncertain efficacy and safety margins of the anaesthetic agents (von Borell et al., 2009).

Research has also helped to eliminate some invasive procedures. Tail-docking of dairy cattle was formerly thought to improve cow cleanliness and udder health, but substantial research has not supported these claims (Tucker et al., 2001; Fulwider et al., 2008). Tail-docking prevents cattle from effectively removing flies from their hindquarters (Eicher and Dailey, 2002). On this basis, tail-docking is banned, discouraged or declining in many countries (Sutherland and Tucker, 2011). 


\section{The handling of animals should foster a positive relationship between humans and animals and should not cause injury, panic, lasting fear or avoidable stress}

Many studies have demonstrated the importance of a positive human-animal relationship for reducing stress and facilitating high productivity in farm animals (Waiblinger et al., 2006; Hemsworth and Coleman, 2011). Negative handling, for example using physical force, electric shock, shouting and rapid movement, can affect the health of animals. Harsh handling of chickens can depress immune function (Gross and Siegel, 1979) and can cause bruises, dislocated joints and broken bones (Gregory and Wilkins, 1989; Newberry et al., 1999). A negative human-animal relationship, typically demonstrated by animals showing fear and avoidance of humans, is a risk factor for lameness in dairy cows (Chesterton et al., 1989; Rouha-Mulleder et al., 2009).

Negative handling, when imposed briefly but regularly, can result in fear responses, together with physiological stress responses and reductions in rates of growth and reproductive performance, particularly in pigs (Gonyou et al., 1986; Hemsworth and Barnett, 1991). In dairy cattle, negative handling increases stress and 'residual' milk (milk not released during milking), with the result that overall milk yield may be reduced (Rushen et al., 1999). These effects help to explain why milk production tends to be lower on dairy farms where animals commonly show fear responses toward humans (Hemsworth et al., 2000).

The equipment used to handle animals can have important effects. Overuse of electric prods when pigs are moved can cause severe stress, leading to increased lactate and glucose levels, and poorer pork quality if negative handling occurs just before slaughter (Hambrecht et al., 2005; Edwards et al., 2010). In cattle, the use of electric prods before slaughter is associated with higher levels of vocalization (Grandin, 1998, 2001), increased stress (Hemsworth et al., 2011) and poorer meat quality (Warner et al., 2007). Manual catching of meat chickens for transportation, as is typically done on commercial farms, can lead to stress responses (Duncan et al., 1986) together with bruising and other injuries, whereas well-designed automated systems can reduce these problems (Lacy and Czarick, 1998; Knierim and Gocke, 2003; Delezie et al., 2006).

Selection of animal handlers provides an important opportunity to improve animal welfare and productivity. Studies in dairy, pork and poultry production show that handlers with positive attitudes toward animals (who believe, for example, that animals are sensitive to handling and should be handled in a pleasant, non-threatening manner) often achieve greater commercial performance (Seabrook, 1984; Hemsworth and Coleman, 2011). Research in Australian pig production has shown that measures of attitude, empathy, work reliability and job satisfaction are useful in identifying effective animal handlers (Coleman, 2004).

\section{Owners and handlers should have sufficient skill and knowledge to ensure that animals are treated in accordance with these principles}

Research with dairy cattle and pigs has shown that animal handling and productivity can be improved through training programmes aimed at improving attitudes and behaviour of handlers towards their animals (Coleman et al., 2000; Hemsworth et al., 2002). Training in specific skills can also be of benefit; for example, training handlers to move animals appropriately can reduce or eliminate the need for electric prods (Grandin, 2010) and the use of good handling techniques can reduce injuries when laying hens are removed from cages (Newberry et al., 1999). 


\section{Discussion}

Traditionally, the field of 'animal husbandry' included the feeding, breeding, health care, handling, management and housing of animals. Especially during the 20th century, a number of scientific disciplines began to provide a more rigorous basis for specific aspects of animal husbandry. Notably, research on nutrition, genetics, reproductive physiology and veterinary medicine contributed to better feeding, breeding and health care of animals. At that time, however, there was little comparable research on animal handling, management and housing. Research on animal welfare, drawing on animal behaviour, stress physiology, veterinary epidemiology and many other fields, is now providing a scientific basis for those aspects of animal husbandry for which previously there was a relative paucity of research. Research on animal welfare is also providing a framework for addressing other issues, such as the negative effects of extreme genetic selection and artificial diets. In complementing more established fields of animal science, research on animal welfare is helping to put animal husbandry on a more comprehensive scientific foundation.

Despite this complementary role, animal welfare science departs from conventional animal science in a number of important respects. Traditional animal science generally has focused on enhancing the productivity, efficiency or profitability of herds and flocks as the primary goal, while effects on the welfare of individual animals were seen as secondary (Mellor et al., 2009). Animal welfare science treats the welfare of the individual animal as the primary concern and improvements in productivity and efficiency as correlated benefits. Nonetheless, this focus on individuals and their welfare will often contribute to economically important aspects of animal production. Welfare problems, such as lameness, injury, social stress and fear of handlers, can result in substantial production problems for many species; animal welfare science provides new tools and insights to address these issues. For example, a focus on the gait of individual cattle has led to a better understanding of lameness and how to prevent it (Chapinal et al., 2009), and studies of the fear reactions of animals have allowed many insights into production-limiting stress caused by handling (Hemsworth and Coleman, 2011).

The General Principles and the underlying research provide the foundation of 'science-based' animal welfare standards, but the term 'science-based' requires some clarification in this context. Animal welfare standards are generally designed to respond to several different concerns about the quality of life of animals, notably the basic health and biological functioning of animals, their affective states (especially unpleasant states, such as fear, pain and frustration) and the ability of animals to live in a manner that suits their natural behaviour and other adaptations (Fraser, 2008). These concerns often coincide. For example, foot lesions are a problem of basic health, they are likely to cause pain and they may prevent an animal from carrying out important types of natural behaviour.

However, the three concerns are sufficiently different that addressing any one may not lead to a high level of animal welfare when judged by the others. For example, confinement systems with disease barriers may provide excellent protection from infectious disease, but may also result in animals being unable to carry out much of their natural behaviour. Conversely, outdoor systems may allow animals to carry out natural behaviour, but subject them to predation and extreme weather. Due to such discrepancies, different animal welfare standards have been developed to achieve different goals (Fraser, 2006); for example, some animal welfare standards specify a maximum of $25 \mathrm{ppm}$ ammonia because higher levels affect basic health, while other standards specify lower values to avoid levels that animals find aversive. Similarly, some standards regarding cages for laying hens require sufficient space to prevent reductions in bird health and productivity, while others also require provision of a perch and nest box in order to accommodate types of natural behaviour that the birds are motivated to perform (Fraser, 2008). 
As these examples illustrate, the process of setting science-based standards involves two steps. The first is a policy decision, often based on a combination of political and ethical considerations, on what animal welfare goals to pursue, ranging from simple survival and satisfactory productivity, through to more comprehensive goals, such as prevention of pain and the accommodation of natural behaviour. This initial decision is often tacit rather than explicit. The second step is to use scientific research to identify the specific requirements needed to meet the goals. Thus, animal welfare standards, even when based on science, still involve policy decisions about which animal welfare goals the standards are intended to address.

To date, a good deal of animal welfare research has been done in response to concerns about animals in intensive production systems. As a result, much research has focused on intensive housing and many animal welfare standards and reforms relate to housing and other environmental factors. However, animal welfare is strongly influenced by many other factors, including genetics, nutrition, disease prevention and the behaviour of handlers. There is a need for further research on how each of these factors contributes to animal welfare in different production systems and how to solve animal welfare problems caused by some existing breeding and feeding practices. More broadly, there is a need for research to take an integrative approach built on the view that good animal welfare requires a complex fit between genetics, housing, handling and other elements of animal husbandry.

\section{Conclusions}

The ten 'General Principles for the Welfare of Animals in Livestock Production Systems' adopted by the World Organisation for Animal Health provide a framework to guide the development of specific animal welfare standards for various animal species. The principles are based on decades of multi-disciplinary research relevant to animal welfare. Research on animal welfare complements work in traditional fields to provide a more comprehensive scientific basis for the care and management of animals.

${ }^{1}$ See http://www.oie.int/en.

\section{Conflict of interest statement}

None of the authors of this paper has a financial or personal relationship with other people or organisations that could inappropriately influence or bias the content of the paper.

\section{Acknowledgements}

Preparation of this paper was supported by the NSERC Industrial Research Chair in Animal Welfare at the University of British Columbia. The contribution of Marek Špinka was supported by Grant MZE0002701404. 


\section{References}

Adams, A.W., Craig, J.V., 1985. Effect of crowding and cage shape on productivity and profitability of caged layers: A survey. Poultry Science 64, 238-242.

Al-Mashhadani, E., Beck, M.M., 1985. Effect of atmospheric ammonia on the surface ultrastructure of the lung and trachea of broiler chicks. Poultry Science 64, 2056-2061.

Appleby, M.C., Lawrence, A.B., 1987. Food restriction as a cause of stereotypic behaviour in tethered gilts. Animal Production 45, 103-110.

Appleby, M.C., Mench, J.A., Olsson, I.A.S., Hughes, B.O. (Eds.), 2011. Animal Welfare, Second Ed. CABI, Wallingford, England, UK, 336 pp.

Arey, D.S., 1999. Time course for the formation and disruption of social organisation in group-housed sows. Applied Animal Behaviour Science 62, 199-207.

AVMA, 2013. AVMA Guidelines for the Euthanasia of Animals, 2013 Edition. American Veterinary Medical Association (AVMA), Schaumburg, Illinois, USA, 102 pp. https://www.avma.org/KB/Policies/Documents/euthanasia.pdf (accessed 11 April 2013).

Barnett, J.L., Cronin, G.M., McCallum, T.H., Newman, E.A., Hennessy, D.P., 1996. Effects of grouping unfamiliar adult pigs after dark, after treatment with amperozide and by using pens with stalls, on aggression, skin lesions and plasma cortisol concentrations. Applied Animal Behaviour Science 50, 121133.

Barnett, J.L., Hemsworth, P.H., Cronin, G.M., Newman, E.A., McCallum, T.H., Chilton, D., 1992. Effects of pen size, partial stalls and method of feeding on welfare-related behavioural and physiological responses of group-housed pigs. Applied Animal Behaviour Science 34, 207-220.

Beker, A., Vanhooser, S.L., Swartzlander, J.H., Teeter, R.G., 2004. Atmospheric ammonia concentration effects on broiler growth and performance. Journal of Applied Poultry Research 13, 5-9.

Bell, D., Chase, B., Douglass, A., Hester, P., Mench, J., Newberry, R., Shea-Moore, M., Stanker, L., Swanson, J., Armstrong, J., 2004. UEP uses scientific approach in its establishment of welfare guidelines. Feedstuffs 76, 1-9.

Blokhuis, H.J., 1983. The relevance of sleep in poultry. World's Poultry Science Journal 39, 33-37.

Blokhuis, H.J., 1984. Rest in poultry. Applied Animal Behaviour Science 12, 289-303.

Boissy, A., Le Neindre, P., 1997. Behavioral, cardiac and cortisol responses to brief peer separation and reunion in cattle. Physiology and Behavior 61, 693-699.

Boyle, L.A., Regan, D., Leonard, F.C., Lynch, P.B., Brophy, P., 2000. The effect of mats on the welfare of sows and piglets in the farrowing house. Animal Welfare 9, 39-48.

Bracke, M.B.M., Spoolder, H.A.M., 2011. Review of wallowing in pigs: Implications for animal welfare. Animal Welfare 20, 347-363.

Breuer, K., Sutcliffe, M.E.M., Mercer, J.T., Rance, K.A., O'Connell, N.E., Sneddon, I.A., Edwards, S.A., 2005. Heritability of clinical tail-biting and its relation to performance traits. Livestock Production Science 93, 87-94. 
Broom, D.M., Johnson, K.G., 1993. Stress and Animal Welfare. Chapman \& Hall, London, England, UK, $211 \mathrm{pp}$.

Broom, D.M., Fraser, A.F., 2007. Domestic Animal Behaviour and Welfare, Fourth Ed. CABI, Wallingford, England, UK, $540 \mathrm{pp}$.

Chaloupková, H., Illmann, G., Bartoš, L., Špinka, M., 2007. Effect of the pre-weaning housing system on play and agonistic behaviour in domestic pigs. Applied Animal Behaviour Science 103, 25-34.

Chapinal, N., de Passillé, A.M., Weary, D.M., von Keyserlingk, M.A.G., Rushen, J., 2009. Using gait score, walking speed, and lying behavior to detect hoof lesions in dairy cows. Journal of Dairy Science $92,4365-4374$.

Chauve, C., 1998. The poultry red mite Dermanyssus gallinae (de Geer, 1778): Current situation and future prospects for control. Veterinary Parasitology 79, 239-245.

Chesterton, R.N., Pfeiffer, D.U., Morris, R.S., Tanner, C.M., 1989. Environmental and behavioural factors affecting the prevalence of foot lameness in New Zealand dairy herds - A case-control study. New Zealand Veterinary Journal 37, 135-142.

Coleman, G.J., 2004. Personnel management in livestock industries. In: Benson, G.J., Rollin, B.E. (Eds.), The Well-Being of Farm Animals: Challenges and Solutions. Blackwell, Ames, lowa, USA, pp. 167-181.

Coleman, G.J., Hemsworth, P.H., Hay, M., Cox, M., 2000. Modifying stockperson attitudes and behaviour towards pigs at a large commercial farm. Applied Animal Behaviour Science 66, 11-20.

Cutler, G.J., 2002. Vaccines and vaccination. In: Bell, D.D., Weaver, W.D., Jr. (Eds.), Commercial Chicken Meat and Egg Production, Fifth Ed. Springer, Heidelberg, Germany, pp. 451-461.

Dana, N., vander Waaij, L.H., Dessie, T., van Arendonk, J.A.M., 2010. Production objectives and trait preferences of village poultry producers of Ethiopia: Implications for designing breeding schemes utilizing indigenous chicken genetic resources. Tropical Animal Health and Production 42, 1519-1529.

Dawkins, M.S., 1977. Do hens suffer in battery cages? Environmental preferences and welfare. Animal Behaviour 25, 1034-1046.

Dawkins, M.S., 2004. Using behaviour to assess animal welfare. Animal Welfare 13, S3-S7.

Dawkins, M.S., 2008. The science of animal suffering. Ethology 114, 937-945.

Delezie, E., Lips, D., Lips, R., Decuypere, E., 2006. Is the mechanisation of catching broilers a welfare improvement? Animal Welfare 15, 141-147.

de Jong, I.C., Guémené, D., 2011. Major welfare issues in broiler breeders. World's Poultry Science Journal $67,73-82$.

de Leeuw, J.A., Bolhuis, J.E., Bosch, G., Gerrits, W.J.J., 2008. Effects of dietary fibre on behaviour and satiety in pigs. Proceedings of the Nutrition Society $67,334-342$.

Dessie, T., Taye, T., Dana, N., Ayalew, W., Hanotte, O., 2011. Current state of knowledge on phenotypic characteristics of indigenous chickens in the tropics. World's Poultry Science Journal $67,507-516$. 
D’Mello, J.P.F., Placinta, C.M., Macdonald, A.M.C., 1999. Fusarium mycotoxins: A review of global implications for animal health, welfare and productivity. Animal Feed Science and Technology 80, 183205.

Donaldson, T.M., Newberry, R.C., Špinka, M., Cloutier, S., 2002. Effects of early play experience on play behaviour of piglets after weaning. Applied Animal Behaviour Science 79, 221-231.

Donham, K.J., Yeggy, J., Dague, R.R., 1988. Production rates of toxic gases from liquid swine manure Health implications for workers and animals in swine confinement buildings. Biological Wastes 24, 161173.

Dudink, S., Simonse, H., Marks, I., de Jonge, F.H., Spruijt, B.M., 2006. Announcing the arrival of enrichment increases play behaviour and reduces weaning-stress-induced behaviours of piglets directly after weaning. Applied Animal Behaviour Science 101, 86-101.

Duncan, I.J.H., 1970. Frustration in the fowl. In: Freeman, B.M., Gordon, R.F. (Eds.), Aspects of Poultry Behaviour. British Poultry Science, Edinburgh, Scotland, UK, pp. 15-31.

Duncan, I.J.H., Kite, V.G., 1987. Some investigations into motivation in the domestic fowl. Applied Animal Behaviour Science 18, 387-388.

Duncan, I.J.H., Kite, V.G., 1989. Nest site selection and nest building behaviour in domestic fowl. Animal Behaviour 37, 215-231.

Duncan, I.J.H., Slee, G.S., Kettlewell, P., Berry, P., Carlisle, A.J., 1986. Comparison of the stressfulness of harvesting broiler chickens by machine and by hand. British Poultry Science 27, 109-114.

Duve, L.R., Jensen, M.B., 2011. The level of social contact affects social behaviour in pre-weaned dairy calves. Applied Animal Behaviour Science 135, 34-43.

Edwards, L.N., Grandin, T., Engle, T.E., Porter, S.P., Ritter, M.J., Sosnick, A.A., Anderson, D.B., 2010. Use of exsanguination blood lactate to assess the quality of pre-slaughter handling. Meat Science 86, 384-390.

Edwards, S.A., 2002. Perinatal mortality in the pig: Environmental or physiological solutions? Livestock Production Science 78, 3-12.

Eicher, S.D., Dailey, J.W., 2002. Indicators of acute pain and fly avoidance behaviors in Holstein calves following tail-docking. Journal of Dairy Science 85, 2850-2858.

Ekesbo, I., 1966. Disease incidence in tied and loose housed dairy cattle and causes of this incidence: Variation with particular reference to the cowshed type. Acta Agriculturæ Scandinavica Supplement 15, $1-74$.

Erb, H.N., Smith, R.D., Oltenacu, P.A., Guard, C.L., Hillman, R.B., Powers, P.A., Smith, M.C., White, M.E., 1985. Path model of reproductive disorders and performance, milk fever, mastitis, milk yield and culling in Holstein cows. Journal of Dairy Science 68, 3337-3349.

Evans, N.J., Timofte, D., Isherwood, D.R., Brown, J.M., Williams, J.M., Sherlock, K., Lehane, M.J., Murray, R.D., Birtles, R.J., Hart, C.A., Carter, S.D., 2012. Host and environmental reservoirs of infection for bovine digital dermatitis treponemes. Veterinary Microbiology 156, 102-109. 
FAWC, 2003. Report on the Welfare of Farmed Animals at Slaughter or Killing. Part 1: Red Meat Animals. Farm Animal Welfare Council (FAWC), London, England, UK, 72 pp. http://www.fawc.org.uk/reports/pb8347.pdf (accessed 3 October 2012).

Fjeldaas, T., Sofstad, Å.M., Østerås, O., 2011. Locomotion and claw disorders in Norwegian dairy cows housed in freestalls with slatted concrete, solid concrete, or solid rubber flooring in the alleys. Journal of Dairy Science 94, 1243-1255.

Flower, F.C., de Passillé, A.M., Weary, D.M., Sanderson, D.J., Rushen, J., 2007. Softer, higher-friction flooring improves gait of cows with and without sole ulcers. Journal of Dairy Science 90, 1235-1242.

Follensbee, M.E., Duncan, I.J.H., Widowski, T.M., 1992. Quantifying nesting motivation of domestic hens. Proceedings of the Meeting of the American Society of Animal Science and International Society of Applied Ethology, Pittsburgh, Pennsylvania, USA, 8-11 August 1992. Journal of Animal Science 70, 164.

Fox, L.K., Gay, J.M., 1993. Contagious mastitis. Veterinary Clinics of North America: Food Animal Practice 9, 475-487.

Fraser, D., 1975. The "teat order" of suckling pigs. II. Fighting during suckling and the effects of clipping the eye teeth. Journal of Agricultural Science 84, 393-399.

Fraser, D., 2006. Animal welfare assurance programs in food production: A framework for assessing the options. Animal Welfare 15, 93-104.

Fraser, D., 2008. Understanding Animal Welfare: The Science in its Cultural Context. Wiley-Blackwell, Oxford, England, UK, 324 pp.

Fraser, D., Nicol, C.J., 2011. Preference and motivation research. In: Appleby, M.C., Mench, J.A., Olsson, I.A.S., Hughes, B.O. (Eds.), Animal Welfare, Second Ed. CABI, Wallingford, England, UK, pp. 183-199.

Fraser, D., Thompson, B.K., 1991. Armed sibling rivalry by domestic piglets. Behavioral Ecology and Sociobiology 29, 9-15.

Fregonesi, J.A., Tucker, C.B., Weary, D.M., 2007a. Overstocking reduces lying time in dairy cows. Journal of Dairy Science 90, 3349-3354.

Fregonesi, J.A., Veira, D.M., von Keyserlingk, M.A.G., Weary, D.M., 2007b. Effects of bedding quality on lying behavior of dairy cows. Journal of Dairy Science $90,5468-5472$.

Fulwider, W.K., Grandin, T., Rollin, B.E., Engle, T.E., Dalsted, N.L., Lamm, W.D., 2008. Survey of dairy management practices on one hundred thirteen North Central and Northeastern United States dairies. Journal of Dairy Science 91, 1686-1692.

Gamble, H.R., Bush, E., 1999. Seroprevalence of Trichinella infection in domestic swine based on the National Animal Health Monitoring System's 1990 and 1995 swine surveys. Veterinary Parasitology 80, 303-310.

Gentle, M.J., 2011. Pain issues in poultry. Applied Animal Behaviour Science 135, 252-258.

Glatz, P.C. (Ed.), 2005. Poultry Welfare Issues: Beak Trimming. Nottingham University Press, Nottingham, England, UK, 174 pp. 
Godden, S., Bey, R., Lorch, K., Farnsworth, R., Rapnicki, P., 2008. Ability of organic and inorganic bedding materials to promote growth of environmental bacteria. Journal of Dairy Science 91, 151-159.

Gonyou, H.W., Hemsworth, P.H., Barnett, J.L., 1986. Effects of frequent interactions with humans on growing pigs. Applied Animal Behaviour Science 16, 269-278.

Grandin, T., 1998. The feasibility of using vocalization scoring as an indicator of poor welfare during slaughter. Applied Animal Behaviour Science 56, 121-125.

Grandin, T., 2001. Cattle vocalizations are associated with handling and equipment problems in slaughter plants. Applied Animal Behaviour Science 71, 191-201.

Grandin, T., 2010. Improving Animal Welfare: A Practical Approach. CABI, Wallingford, England, UK, 328 pp.

Gregory, N.G., 1998. Animal Welfare and Meat Science. CABI, New York, USA, 304 pp.

Gregory, N.G., Wilkins, L.J., 1989. Broken bones in domestic fowl: Handling and processing damage in end-of-lay battery hens. British Poultry Science Journal 30, 555-562.

Gross, W.B., Siegel, P.B., 1979. Adaptation of chickens to their handlers and experimental results. Avian Diseases 23, 708-714.

Grout, A.A., Veira, D.M., Weary, D.M., von Keyserlingk, M.A.G., Fraser, D., 2006. Differential effects of sodium and magnesium sulphate on water consumption by beef cattle. Journal of Animal Science 84, 1252-1258.

Gygax, L., Neisen, G., Wechsler, B., 2009. Differences between single and paired heifers in residency in functional areas, length of travel path, and area used throughout days 1-6 after integration into a free stall dairy herd. Applied Animal Behaviour Science 120, 49-55.

Gygax, L., Neisen, G., Wechsler, B., 2010. Socio-spatial relationships in dairy cows. Ethology 116, 1023.

Hambrecht, E., Esser, J.J., Newman, D.J., Smits, C.H.W., derHartog, L.A., Vestegan, M.W.A., 2005. Negative effects of stress immediately before slaughter on pork quality are aggravated by suboptimal transport and lairage conditions. Journal of Animal Science 83, 440-448.

Hampson, D.J., Fellström, C., Thomson, J.R., 2006. Swine dysentery. In: Straw, B.E., Zimmerman, J.J., D’Allaire, S., Taylor, D.J. (Eds.), Diseases of Swine, Ninth Ed. Blackwell, Oxford, UK, pp. 785-805.

Hansen, L.L., Hagelsø, A.M., Madsen, A., 1982. Behavior results and performance of bacon pigs fed 'ad libitum' from one or several hoppers. Applied Animal Ethology 8, 307-334.

Hemsworth, P.H., Barnett, J.L., 1991. The effects of aversively handling pigs either individually or in groups on their behaviour, growth and corticosteroids. Applied Animal Behaviour Science 30, 61-72.

Hemsworth, P.H., Coleman, G.J., 2011. Human-Livestock Interactions: The Stockperson and the Productivity and Welfare of Farmed Animals, Second Ed. CABI, Wallingford, England, UK, 208 pp.

Hemsworth, P.H., Coleman, G.J., Barnett, J.L., Borg, S., 2000. Relationships between human-animal interactions and productivity of commercial dairy cows. Journal of Animal Science 78, 2821-2831. 
Hemsworth, P.H., Coleman, G.J., Barnett, J.L., Borg, S., Dowling, S., 2002. The effects of cognitive behavioral intervention on the attitude and behavior of stockpersons and the behavior and productivity of commercial dairy cows. Journal of Animal Science 80, 68-78.

Hemsworth, P.H., Rice, M., Karlen, M.G., Calleja, L., Barnett, J.L., Nash, J., Coleman, G.J., 2011. Human-animal interactions at abattoirs: Relationships between handling and animal stress in sheep and cattle. Applied Animal Behaviour Science 135, 24-33.

Herskin, M.S., Bonde, M.K., Jorgensen, E., Jensen, K.H., 2011. Decubital shoulder ulcers in sows: A review of classification, pain and welfare consequences. Animal $5,757-766$.

Hester, P.Y., Shea-Moore, M., 2003. Beak trimming egg-laying strains of chickens. World's Poultry Science Journal 59, 458-474.

Houe, H., 1995. Epidemiology of bovine viral diarrhea virus. Veterinary Clinics of North America Food Animal Practice 11, 521-547.

Huertas, S.M., Paranhos da Costa, M., Manteca, X., Galindo, F., Morales, M., 2009. An overview of the application of the animal welfare assessment system in Latin America. In: Keeling, L. (Ed.), An Overview of the Development of the Welfare Quality_Project Assessment Systems. Welfare Quality Report No. 12. Cardiff University, Cardiff, Wales, UK, pp. 79-89.

Huynh, T.T.T., Aarnink, A.J.A., Truong, C.T., Kemp, B., Verstegen, M.W.A., 2006. Effects of tropical climate and water cooling methods on growing pigs' responses. Livestock Science 104, 278-291.

Huzzey, J.M., DeVries, T.J., Valois, P., von Keyserlingk, M.A., 2006. Stocking density and feed barrier design affect the feeding and social behavior of dairy cattle. Journal of Dairy Science 89, 126-133.

Huzzey, J.M., Grant, R.J., Overton, T.R., 2012. Relationship between competitive success during displacements at an overstocked feed bunk and measures of physiology and behavior in Holstein dairy cattle. Journal of Dairy Science 95, 4434-4441.

Iqbal, A., Tripathi, A.K., Wazir, V.S., 2011. Foot rot - An emerging issue in sheep husbandry. International Journal of Livestock Research 1, 5-16.

Jarvis, S., Reed, B.T., Lawrence, A.B., Calvert, S.K., Stevenson, J., 2004. Peri-natal environmental effects on maternal behaviour, pituitary and adrenal activation, and the progress of parturition in the primiparous sow. Animal Welfare 13, 171-181.

Jensen, P., 1986. Observations on the maternal behaviour of free-ranging domestic pigs. Applied Animal Behaviour Science 16, 131-142.

Jensen, P., Buitenhuis, B., Kjaer, J., Zanella, A., Mormède, P., Pizzari, T., 2008. Genetics and genomics of animal behaviour and welfare - Challenges and possibilities. Applied Animal Behaviour Science 113, 383-403.

Jones, E.K.M., Wathes, C.M., Webster, A.J.F., 2005. Avoidance of atmospheric ammonia by domestic fowl and the effect of early experience. Applied Animal Behaviour Science 90, 293-308.

Jones, J.B., Burgess, L.R., Webster, A.J.F., Wathes, C.M., 1996. Behavioural responses of pigs to atmospheric ammonia in a chronic choice test. Animal Science 63, 437-445. 
Kilbride, A.L., Gillman, C.E., Ossent, P., Green, L.E., 2009. A cross-sectional study of the prevalence of lameness in finishing pigs, gilts and pregnant sows and associations with limb lesions and floor types on commercial farms in England. Animal Welfare 18, 215-224.

Knierim, U., Gocke, A., 2003. Effect of catching broilers by hand or machine on rates of injuries and deadon-arrival. Animal Welfare 12, 63-73.

Lacy, M.P., Czarick, M., 1998. Mechanical harvesting of broilers. Poultry Science 77, 1794-1797.

Lawrence, A.B., Conington, J., Simm, G., 2004. Breeding and animal welfare: Practical and theoretical advantages of multi-trait selection. Animal Welfare 13, 191-196.

Lawrence, A.B., Terlouw, E.M.C., 1993. A review of the behavioural factors involved in the development and continued performance of stereotypic behaviours in pigs. Journal of Animal Science 71, 2815-2825.

Lay, D.C., Friend, T.H., Grissom, K.K., Bowers, C.L., Mal, M.E., 1992. Effects of freeze or hot-iron branding of Angus calves on some physiological and behavioural indicators of stress. Applied Animal Behaviour Science 33, 137-147.

Lay, D.C., Fulton, R.M., Hester, P.Y., Karcher, D.M., Kjaer, J.B., Mench, J.A., Mullens, B.A., Newberry, R.C., Nicol, C.J., O'Sullivan, N.P., Porter, R.E., 2011. Hen welfare in different housing systems. Poultry Science 90, 278-294.

Madec, F., Rose, N., Grasland, B., Cariolet, R., Jestin, A., 2008. Post-weaning multi-systemic wasting syndrome and other PCV2-related problems in pigs: A 12-year experience. Transboundary and Emerging Diseases 55, 273-283.

Marchant-Forde, R.M., Fahey, A.G., Cheng, H.W., 2008. Comparative effects of infrared and one-third hot-blade trimming on beak topography, behavior and growth. Poultry Science 87, 1474-1483.

Martin, M., 2011. Biosecurity and disease control - the problems defined. In: Owen, R.L. (Ed.), A Practical Guide for Managing Risk in Poultry Production. American Association of Avian Pathologists, Jacksonville, North Carolina, USA, pp. 1-11.

Martino, S., Prieto, M., Boroski, V., Cesar, D., Huertas, S., 2011. Identification and validation of factors affecting the welfare of dairy cattle in Uruguay. In: Köfer, J., Schobesberger, H. (Eds), Animal Hygiene and Sustainable Livestock Production. Proceedings of the XVth International Congress of the International Society for Animal Hygiene, Vienna, Austria, 3-7 July 2011, vol. 3, pp. 1037-1039.

McKeegan, D.E.F., Philbey, A.W., 2012. Chronic neurophysiological and anatomical changes associated with infrared beak treatment and their implications for laying hen welfare. Animal Welfare 21, 207-217.

Mearns, R., 2007. Other infectious causes of abortion. In: Aitken, I.D. (Ed.), Diseases of Sheep, Fourth Ed. Blackwell, Oxford, England, UK, pp. 127-136.

Mellor, D.J., Stafford, K.J., 2000. Acute castration and/or tailing distress and its alleviation in lambs. New Zealand Veterinary Journal 48, 33-43.

Mellor, D.J., Patterson-Kane, E., Stafford, K.J., 2009. The Sciences of Animal Welfare. Wiley-Blackwell, Oxford, England, UK, 198 pp. 
Mench, J.A., 2002. Broiler breeders: Feed restriction and welfare. World's Poultry Science Journal 58, 23-29.

Meunier-Salaun, M.C., Edwards, S.A., Robert, S., 2001. Effect of dietary fibre on the behaviour and health of the restricted fed sow. Animal Feed Science and Technology 90, 53-69.

Minton, J.E., Coppinger, T.R., Reddy, P.G., Davis, W.C., Blecha, F., 1992. Repeated restraint and isolation stress alters adrenal and lymphocyte functions and some leukocyte differentiation antigens in lambs. Journal of Animal Science 70, 1126-1132.

Mirkena, T., Duguma, G., Haile, A., Tibbo, M., Okeyo, A.M., Wurzinger, M., Sölkner, J., 2010. Genetics of adaptation in domestic farm animals: A review. Livestock Science 132, 1-12.

Muir, W.M., Craig, J.V., 1998. Improving animal well-being through genetic selection. Poultry Science 77, 1781-1788.

Murray, R.D., Cartwright, T.A., Downham, D.Y., Murray, M.A., de Kruif, A., 2002. Comparison of external and internal pelvic measurements of Belgian blue cattle from sample herds in Belgium and the United Kingdom. Reproduction in Domestic Animals 37, 1-7.

Neisen, G., Wechsler, B., Gygax, L., 2009. Effects of the introduction of single heifers or pairs of heifers into dairy-cow herds on the temporal and spatial associations of heifers and cows. Applied Animal Behaviour Science 119, 127-136.

Newberry, R.C., Webster, A.B., Lewis, N.J., van Arnam, C., 1999. Management of spent hens. Journal of Applied Animal Welfare Science 2, 13-29.

OIE, 2012. Introduction to the recommendations for animal welfare. In: Terrestrial Animal Health Code, 21st Ed. World Organisation for Animal Health (OIE), Paris, France, Article 7.1.4..

Olsson, I.A.S., Keeling, L.J., 2002. The push-door for measuring motivation in hens: Laying hens are motivated to perch at night. Animal Welfare 11, 11-19.

Oostindjer, M., Van Den Brand, H., Kemp, B., Bolhuis, J.E., 2011. Effects of environmental enrichment and loose housing of lactating sows on piglet behaviour before and after weaning. Applied Animal Behaviour Science 134, 31-41.

Pearson De Vaccaro, L., 1990. Survival of European dairy breeds and their crosses with zebus in the tropics. Animal Breeding Abstracts 58, 437-446.

Phillips, C.J.C., Rind, M.I., 2001. The effects on production and behavior of mixing uniparous and multiparous cows. Journal of Dairy Science 84, 2424-2429.

Phillips, P.A., Fraser, D., Buckley, D.J., 1992. Simulation tests on the effect of floor temperature on leg abrasions in piglets. Transactions of the American Society of Agricultural Engineers 35, 999-1003.

Porter, V., 2002. Mason's World Dictionary of Livestock Breeds, Types, and Varieties. CABI, Wallingford, England, UK, 400 pp.

Proudfoot, K.L., Veira, D.M., Weary, D.M., von Keyserlingk, M.A.G., 2009. Competition at the feed bunk changes the feeding, standing, and social behavior of transition dairy cows. Journal of Dairy Science 92 , 3116-3123. 
Prunier, A., Mounier, A.M., Hay, M., 2005. Effects of castration, tooth resection, or tail docking on plasma metabolites and stress hormones in young pigs. Journal of Animal Science 83, 216-222.

Quarles, C.C.L., Kling, H.F., 1974. Evaluation of ammonia and infections bronchitis vaccination stress on broiler performance and carcass quality. Poultry Science 53, 1592-1596.

Rault, J.L., 2012. Friends with benefits: Social support and its relevance for farm animal welfare. Applied Animal Behaviour Science 136, 1-14.

Rauw, W.M., Kanis, E., Noordhuizen-Stassen, E.N., Grommers, F.J., 1998. Undesirable side effects of selection for high production efficiency in farm animals: A review. Livestock Production Science 56, 1533.

Robert, S., Thompson, B.K., Fraser, D., 1995. Selective tooth clipping in the management of low birth weight piglets. Canadian Journal of Animal Science 75, 285-289.

Rouha-Mulleder, C., Iben, C., Wagner, E., Laaha, G., Troxler, J., Waiblinger, S., 2009. Relative importance of factors influencing the prevalence of lameness in Austrian cubicle loose-housed dairy cows. Preventive Veterinary Medicine 92, 123-133.

Ruis, M.A.W., de Groot, J., te Brake, J.H.A., Ekkel, E.D., van De Burgwal, J.A., Erkens, J.H.F., Engel, B., Buist, W.G., Blokhuis, H.J., Koolhaas, J.M., 2001. Behavioural and physiological consequences of acute social defeat in growing gilts: Effects of the social environment. Applied Animal Behaviour Science 70, 201-225.

Rushen, J., de Passillé, A.M.B., Munksgaard, L., 1999. Fear of people by cows and effects on milk yield, behavior and heart rate at milking. Journal of Dairy Science 82, 720-727.

Rydhmer, L., Zamaratskaia, G., Andersson, H.K., Algers, B., Guillemet, R., Lundstrom, K., 2006. Aggressive and sexual behaviour of growing and finishing pigs reared in groups, without castration. Acta Agriculturae Scandinavica A 56, 109-119.

Salak-Johnson, J.L., Niekamp, S.R., Rodriguez-Zas, S.L., Ellis, M., Curtis, S.E., 2007. Space allowance for dry, pregnant sows in pens: Body condition, skin lesions and performance. Journal of Animal Science 85, 1758-1769.

Savory, C.J., Maros, K., 1993. Influence of degree of food restriction, age and time of day on behaviour of broiler breeder chickens. Behavioural Processes 29, 179-190.

Schwartzkopf-Genswein, K.S., Stookey, J.M., Crowe, T.G., Genswein, B.M., 1998. Comparison of image analysis, exertion force, and behavior measurements for use in the assessment of beef cattle responses to hot-iron and freeze branding. Journal of Animal Science 76, 972-979.

Scott, K., Guy, J.H., Edwards, S.A., 2009. Validation of behaviour around resting in pigs. In: Forkman, B., Keeling, L. (Eds.), Assessment of Animal Welfare Measures for Sows, Piglets and Fattening Pigs. Welfare Quality Report No. 10. Cardiff University, Cardiff, Wales, UK, pp. 39-55.

Scott, P.R., 2007. Listeriosis. In: Aitken, I.D. (Ed.), Diseases of Sheep, Fourth Ed. Blackwell, Oxford, England, UK, pp. 255-259.

Seabrook, M.F., 1984. The psychological interaction between the stockman and his animals and its influence on performance of pigs and dairy cows. Veterinary Record 115, 84-87. 
Shimshony, A., Chaudry, M.M., 2005. Slaughter of animals for human consumption. Review Scientifique et Technique de l'Office International des Épizooties 24, 693-710.

Shivaprasad, H.L., Barrow, P., 2008. Pullorum disease and fowl typhoid. In: Saif, Y.M., Fadley, A.M., Glisson, J.R., McDougald, L.R., Nolan, L.K., Swayne, D.E. (Eds.), Diseases of Poultry, 12th Ed. Blackwell, Ames, lowa, USA, pp. 620-634.

Siegel, P.B., Wisman, E.L., 1966. Changes in appetite and feed utilization. Poultry Science 45, 13911397.

Snowder, G.D., Van Vleck, L.D., Cundiff, L.V., Bennett, G.L., 2006. Bovine respiratory disease in feedlot cattle: Environmental, genetic, and economic factors. Journal of Animal Science 84, 1999-2008.

Stafford, K.J., Mellor, D.J., 2005. Dehorning and disbudding distress and its alleviation in calves. The Veterinary Journal 169, 337-349.

Stafford, K.J., Mellor, D.J., 2011. Addressing the pain associated with disbudding and dehorning in cattle. Applied Animal Behaviour Science 135, 226-231.

Stärk, K.D.C., 2000. Epidemiological investigation of the influence of environmental risk factors on respiratory diseases in swine - A literature review. The Veterinary Journal 159, 37-56.

Stewart, M., Stookey, J.M., Stafford, K.J., Tucker, C.B., Rogers, A.R., Dowling, S.K., Verkerk, G.A., Schaefer, A.L., Webster, J.R., 2009. Effects of local anesthetic and a nonsteroidal anti-inflammatory drug on pain responses of dairy calves to hot-iron dehorning. Journal of Dairy Science 92, 1512-1519.

Stookey, J.M., Goonewardene, L.A., 1996. A comparison of production traits and welfare implications between horned and polled beef bulls. Canadian Journal of Animal Science 76, 1-5.

Sutherland, M.A., Tucker, C.B., 2011. The long and short of it: A review of tail docking in farm animals. Applied Animal Behaviour Science 135, 179-191.

Swayne, D.E., 2006. Principles for vaccine protection in chickens and domestic waterfowl against avian influenza. Annals of the New York Academy of Sciences 1081, 174-181.

Tauson, R., 1998. Health and production in improved cage designs. Poultry Science 77, 1820-1827.

Taylor, A.A., Weary, D.M., 2000. Vocal responses of piglets to castration: Identifying procedural sources of pain. Applied Animal Behaviour Science 70, 17-26.

Thogerson, C.M., Hester, P.Y., Mench, J.A., Newberry, R.C., Pajor, E.A., Garner, J.P., 2009. The effect of feeder space allocation on behavior of $\mathrm{Hy}$-Line W-36 hens housed in conventional cages. Poultry Science $88,1544-1552$.

Tucker, C.B., Fraser, D., Weary, D.M., 2001. Tail docking dairy cattle: Effects on cow cleanliness and udder health. Journal of Dairy Science 84, 84-87.

Tucker, C.B., Rogers, A.R., Schütz, K.E., 2008. Effect of solar radiation on dairy cattle behaviour, use of shade and body temperature in a pasture-based system. Applied Animal Behaviour Science 109, 141154. 
Turner, S.P., D'Eath, R.B., Roehe, R., Lawrence, A.B., 2010. Selection against aggressiveness in pigs at re-grouping: Practical application and implications for long-term behavioural patterns. Animal Welfare 19S, 123-132.

van der Fels-Klerx, H.J., Horst, H.S., Dijkhuizen, A.A., 2000. Risk factors for bovine respiratory disease in dairy youngstock in The Netherlands: The perception of experts. Livestock Production Science 66, 35-46.

von Borell, E., Baumgartner, J., Giersing, M., Jaggin, N., Prunier, A., Tuyttens, F.A.M., Edwards, S.A., 2009. Animal welfare implications of surgical castration and its alternatives in pigs. Animal 3, 1488-1496.

von Keyserlingk, M.A.G., Olenick, D., Weary, D.M., 2008. Acute behavioral effects of regrouping dairy cows. Journal of Dairy Science 91, 1011-1016.

Waiblinger, S., Boivin, X., Pedersen, V., Tosi, M.-V., Janczak, A.M., Visser, E.K., Jones, R.B., 2006. Assessing the human-animal relationship in farmed species: A critical review. Applied Animal Behaviour Science 101, 185-242.

Warner, R.D., Ferguson, D.M., Cottrell, J.J., Knee, B.W., 2007. Acute stress induced by the preslaughter use of electric prodders causes tougher beef meat. Australian Journal of Experimental Agriculture 47, 782-788.

Weary, D.M., Niel, L., Flower, F.C., Fraser, D., 2006. Identifying and preventing pain in animals. Applied Animal Behaviour Science 100, 64-76.

Webster, A.B., 2004. Welfare implications of avian osteoporosis. Poultry Science 83, 184-192.

Weitzenbürger, D., Vits, A., Hamann, H., Hewicker-Trautwein, M., Distl, O., 2006. Macroscopic and histopathological alterations of foot pads of laying hens kept in small group housing systems and furnished cages. British Poultry Science 47, 533-543.

Wendt, M., Bickhardt, K., Herzog, A., Fischer, A., Martens, H., Richter, T., 2000. Belastungsmyopathie des schweines und PSE-fleisch: Klinik, pathogenese, ätiologie und tierschutzrechtliche aspekte. Berliner und Münchener Tierärztliche Wochenschrift 113, 173-190.

West, J.W., 2003. Effects of heat stress on production in dairy cattle. Journal of Dairy Science 86, 21312144.

White, R.G., Deschazer, J.A., Tressler, N.J., Borcher, G.M., Davey, S., Warringe, A., Parkhurst, A.M., Milanuk, M.J., Clemens, E.T., 1995. Vocalizations and physiological responses of pigs during castration with and without anesthetic. Journal of Animal Science 73, 381-386.

Whitehead, C.C., 2004. Overview of bone biology in the egg-laying hen. Poultry Science 83, 193-199.

Woods, J., Shearer, J.K., Hill, J., 2010. Recommended on-farm euthanasia practices. In: Grandin, T. (Ed.), Animal Welfare: A Practical Approach. CABI, Wallingford, England, UK, pp. 186-213.

Wood-Gush, D.G.M., Gilbert, A.B., 1973. Some hormones involved in the nesting behaviour of hens. Animal Behaviour 21, 98-103.

Wood-Gush, D.G.M., Duncan, I.J.H., Fraser, D., 1975. Social stress and welfare problems in agricultural animals. In: Hafez, E.S.E. (Ed.), The Behaviour of Domestic Animals, Third Ed. Baillière Tindall, London, pp. 182-200. 